9. Стрішенець О.М. Товарне виробництво і торгівля в Україні (друга половина XVII-кінець XVIII ст.) Монографія. Чернівці. “Місто”, 2009. 304 с.

\title{
References
}

1. Oliynyk, N. (2010). Zarubizhni modeli derzhavnoho rehulyuvannya rynku zhytla: porivnyal'nyy analiz [Foreign models of the state regulation of the housing market: a comparative analysis]. Zb. nauk. pr. NADU - Sb. sciences пр. NAPA, 2, 71-80. [in Ukrainian].

2. Oliynyk, N. (2011). Rozvytok infrastruktury rynku zhytla v Ukrayini: aktual'ni problemy ta napryamy derzhavnoho rehulyuvannya [Development of Housing Market Infrastructure in Ukraine: Current Issues and Directions of State Regulation]. Visn. NADU - Vysn. NAPA, 1, 131-139 [in Ukrainian].

3. Pavlov, K.V. (2017). Rehional'ni osoblyvosti formuvannya konkurentnykh vidnosyn mizh sub"yektamy rynku zhytlovoyi nerukhomosti v Ukrayini [Regional features of the formation of competitive relations between the subjects of the residential real estate market in Ukraine]. Sotsial'no-ekonomichni problemy suchasnoho periodu Ukrayiny DU “Instytut rehional'nykh doslidzhen' imeni M. I. Dolishn'oho NAN Ukrayiny” - Socio-economic problems of the modern period of Ukraine State Enterprise "Institute of Regional Studies named after M.I. Dolyshny of the National Academy of Sciences of Ukraine", 4 (126), 38-42 [in Ukrainian].

4. Pavlov, K.V. (2013). Rehulyuvannya investytsiyno-zhytlovykh vidnosyn v Ukrayini: monohrafiya [Regulation of Investment and Housing Relations in Ukraine: Monograph]. Rivne: NUVGP [in Ukrainian].

5. Pavlov, K.V. (2018). Otsinka konkurentospromozhnosti rehional'nykh rynkiv zhytlovoyi nerukhomosti Ukrayiny: monohrafiya [Assessment of competitiveness of regional markets of residential real estate in Ukraine: monograph]. Lutsk: PJSC "Volyn Regional Printing House" [in Ukrainian].

6. Strishenets, O.M. (2012). Do pytannya pro maybutnye teoriyi rynkovoho fundamentalizmu [On the Future of the Theory of Market Fundamentalism]. Naukovyy visnyk. - Seriya: Ekonomichni nauky / Bukovyns'kyy derzh. finans. un-t. - Scientific herald. - Series: Economics / Bukovina State. finance un, 1, 386-391. [in Ukrainian].

7. Strishenets, O.M., Yelissyeyeva, L.V. \& Lishchuk, V.I. (2014). Ekonomichna teoriya: [navch. posibnyk dlya stud. vyshch. navch. zakl.]. [Economic theory: [curriculum vitae] student guide higher teach ok.], Lutsk: SNU them. Lesia Ukrainka [in Ukrainian].

8. Strishenets, O.M. \& Pavlov, K.V. (2016). Osoblyvosti konkurentnykh vidnosyn na rehional'nykh rynkakh nerukhomosti [Features of competitive relations in the regional real estate markets]. Naukovyy visnyk uzhhorods'koho universytetu. Seriya «Ekonomika». Zbirnyk naukovykh prats - Scientific Bulletin of Uzhgorod University. The series "Economics". Collection of scientific works. Uzhgorod, 1 (47), V.2, 35-38. [in Ukrainian].

9. Strishenets, O.M. (2009). Tovarne vyrobnytstvo i torhivlya v Ukrayini (druha polovyna XVII-kinets XVIII st.) Monohrafiya [Commodity production and trade in Ukraine (second half of the XVII-XVIII centuries.) Monograph], Chernivtsi: "City" [in Ukrainian].

Стаття надійшла до редакції 20.11.2019 р.

УДК 332.

Зайчук Катерина, аспірант,

Східносвропейський національний університет ім. Лесі Українки, кафедра аналітичної економіки та природокористування, м. Луцьк, ORCID ID 0000-0002-7849-988X e-mail: lukianchyk katya@ukr.net

https://doi.org/10.29038/2411-4014-2019-04-149-157

\section{АНАЛІЗ РЕЙТИНГУВАННЯ СОЦАЛЬНО-ЕКОНОМІЧНОЇ АКТИВНОСТІ ЗАХІДНОГО РЕГІОНАЛЬНОГО ТУРИСТИЧНОГО РИНКУ}


У даній статті проведено аналіз рейтингування соціально-економічної активності Західного регіонального туристичного ринку за наступними факторами: кількість населення, середня заробітна плата, кількість обслуговуваних туристів суб'єктами туристичної діяльності, наявність готелів, колективних засобів розміщення, санаторіїв та баз відпочинку, визначено поняття РТР, проведено оцінку рейтингу Волинської, Рівненської, Львівської та Тернопільської областей за соціально-економічними показниками. Вивчаючи туристичний ринок Волинської області, варто простежити формування туристичного ринку в інших сусідніх областях задля створення конкуренції та стимулювання розвитку туризму у своєму регіоні. Це і лягає в основу актуальності даної роботи.

Ключові слова: Західний регіональний туристичний ринок, соціально-економічна активність, туроператор, турагент, методи рейтингування.

Зайчук Екатерина, аспирант,

Восточноевропейский национальный университет им. Леси Украинки, кафедра аналитической экономики и природопользования, г. Луцк

\section{АНАЛИЗ РЕЙТИНГОВАНИЯ СОЦИАЛЬНО-ЭКОНОМИЧЕСКОЙ АКТИВНОСТИ ЗАПАДНОГО РЕГИОНАЛЬНОГО ТУРИСТИЧЕСКОГО РЫНКА}

В данной статье проведен анализ рейтингования социально-экономической активности Западного регионального туристического рынка по следующим факторам: количество населения, средняя заработная плата, количество обслуживаемых туристов субъектами туристической деятельности, наличие отелей, коллективных средств размещения, санаториев и баз отдыха, определено понятие РТР, проведена оценка рейтинга Волынской, Ровенской, Львовской и Тернопольской областей по социально-экономическим показателям. Изучая туристический рынок Волынской области, стоит проследить формирование туристического рынка в других соседних областях для создания конкуренции и стимулирования развития туризма в своем регионе. Это и ложится в основу актуальности данной работы.

Ключевые слова: Западный региональный туристический рынок, социально-экономическая активность, туроператор, турагент, методы рейтингования

Zaychuk Kateryna, PhD student,

Eastern European National University named after Lesya Ukrainka, Chair of Analytical Economics and Resources Management,

Lutsk

\section{ANALYSIS OF RATING OF SOCIO-ECONOMIC ACTIVITY OF THE WESTERN REGIONAL TOURIST MARKET}

This article highlights the ranking of areas by socio-economic indicators. For a full study, we defined the concepts of the regional tourism market and combined 4 regions: Volyn, Rivne, Lviv and Ternopil into the Western Regional Tourist Region (ZRTR). Each region was characterized by the following indicators: population, average wage, number of tourists served, number of collective facilities, number of hotels and similar recreation facilities, number of sanatoriums and recreation centers. The studies were conducted using data from the General Statistics Office of each area. They charted and identified the most optimal area for tourism market development. Next, they built a table where the colors indicated the areas by their position.

Lviv region took 4th place, followed by Volyn region - 3, Rivne region - 2, and Ternopil - 1. That is, the Lviv region received the highest rating. Next, we color-coded the rating of Western Regional Tourism Market areas: the brighter the color, the better the tourism market is compared to other areas. Areas that have been downgraded should pay attention to local regulation and improve their tourism potential by using different development strategies and modernization projects.

Introduction. Studying the tourist market of the Volyn region and its features: structure, functions, types and other, in my opinion, for a deeper study it is worthwhile to analyze the ranking of socio-economic indicators of the Western Regional Tourism Market (ZRTR). Our study covers 4 areas: Volyn, Ternopil, Lviv, and Rivne. With the help 
of this research we will derive a certain rating of areas for the development of the tourist services market and will be able to determine the most optimal area for tourism development in general.

The purpose of the article. The main purpose of this study is to analyze the ranking of socio-economic indicators of the Western Regional Tourism Market

Results. Lviv region took 4th place, followed by Volyn region - 3, Rivne region - 2, and Ternopil - 1. That is, the Lviv region received the highest rating. Next, we color-coded the rating of Western Regional Tourism Market areas: the brighter the color, the better the tourism market is compared to other areas. Areas that have been downgraded should pay attention to local regulation and improve their tourism potential by using different development strategies and modernization projects.

Conclusions. Table 1 shows the ranking positions of the LRTF regions by socio-economic indicators. The lighter the color and the lower the value of the rating, the worse the tourist position of the area compared to the other. It follows that the best situation and the most optimal area for tourism development is the Lviv region. The situation is slightly worse in Volyn and Rivne regions. But not so successful in the development of tourism is the Ternopil region, which requires many recommendations for improving the tourist status of the region.

Therefore, in the perspective of further research it is necessary to focus on, in fact, the methods of regional and local state regulatory bodies, namely the development of the tourist market in the regions. In order to modernize and stimulate the development of the tourism industry in areas that have received low marks in the RDA rating study, it is necessary to identify priority areas of work and find those tourism projects and development strategies that would be most optimal in a given region

Keywords. Western regional tourism market, socio-economic activity, tour operator, travel agent, rating methods.

Постановка наукової проблеми та її значення. Вивчаючи туристичний ринок Волинської області та його особливості: структуру, функції, види та інше, на мою думку, для глибшого дослідження варто провести аналіз рейтингування соціально-економічних показників Західного регіонального туристичного ринку (ЗРТР). Аналіз рейтингування Західного регіонального туристичного ринку дасть нам можливість простежити рівень розвитку туризму в інших областях та створити конкуренцію задля просування туристичного продукту зокрема у Волинській області. Тому для даного аналізу ми об'єднали чотири області: Волинську, Тернопільську, Львівську та Рівненську та назвали його - Західним регіональним туристичним ринком. Назва регіону виникла із-за фізикогеографічного та економічного розташування областей. За допомогою даного дослідження ми виведемо певний рейтинг областей щодо розвитку ринку туристичних послуг та зможемо визначити найоптимальнішу область для розвитку туризму загалом.

Аналіз останніх досліджень і публікацій. Даною проблематикою, а саме визначенням та формуванням регіонального туристичного ринку України займалися такі вчені та науковці: С.В. Сидорук, О.В. Рогова, М.В. Тонкошкур, І.В. Писарева, Т.Д. Павлюк, І.М. Гонак, Н.М. ГобликМаркович, 3.В. Герасимчук, Л.М.Черчик та інші.

Мета і завдання статті. Основною метою даного дослідження $\epsilon$ аналіз рейтингування соціально-економічних показників Західного регіонального туристичного ринку.

Викладення основного матеріалу та обгрунтування отриманих результатів дослідження.

Щоб дослідити дану проблематику, варто визначити поняття регіонального ринку та вдосконалити існуючі підходи до визначення регіонального туристичного ринку іншими вченими та науковцями. Для прикладу В.К. Федорченко у свої працях висловлює поняття регіональний туристичний ринок (РТР) - як соціально-економічну систему, з високим рівнем саморегуляції, де зосереджена повна взаємодія між виробництвом, збутом та споживанням туристичного продукту [11].

О. В. Рогова вважає що регіональний ринок - це товарний ринок, межі якого охоплюють деякі частини областей та регіонів [10].

Л.М. Черчик та 3.В. Герасимчук вважають, що регіональний туристичний ринок - це ринок, який можна розглядати як відкриту систему, яка пов'язана 3 багатьма іншими рангами та господарським комплексом декількох територій чи регіонів [8].

Т.Д. Павлюк має власні переконання визначення регіонального туристичного ринку: це місце де існує конкуренція та постійна взаємодія між товаровиробниками та споживачами туристичних послуг [9]. 
На нашу думку, регіональний туристичний ринок - сукупність певних регіонів чи областей, на механізм формування яких, впливає кількість населення, заробітна плата, кількість суб'єктів туристичної діяльності, наявність туристичних ресурсів та безумовно органи державної та місцевої влади, які формують державну політику у сфері туризму [5], [6].

Отож, регіональний туристичний ринок - це величезна соціально-економічна система, яка постійно пов'язана 3 виробництвом туристичного продукту, його збутом та споживанням туристичних послуг в межах однієї або декількох територій.

Як було згадано вище, Західний регіональний туристичний (ЗРТР) регіон включає в себе Волинську, Рівненську, Тернопільську та Львівську області. Це наше об'єднання областей дасть можливість провести ширше дослідження та визначити, яка область має найоптимальніші умови для вдосконалення та розвитку туристичного ринку в порівнянні з іншими областями.

Для повного та удосконаленого дослідження формування та активізації Західного регіонального туристичного ринку варто проаналізувати соціально-економічну активність чотирьох областей.

Тому проведемо аналіз рейтингування Волинської, Рівненської, Львівської та Тернопільської областей, включаючи наступні фактори соціально-економічної активності: кількість населення, середня заробітна плата, кількість обслуговуваних туристів суб'єктами туристичної діяльності, наявність готелів, колективних засобів розміщення, санаторіїв та баз відпочинку. Даний аналіз рейтингування областей соціально-економічної активності будемо проводити за допомогою методу статистики.

За даними Головного управління статистики у Волинській області кількість населення становила на 1 серпня 2019 року - 1033,3 тис. осіб. Середньомісячна номінальна заробітна плата становила - 8382 грн. Найбільш оплачуваною була робота у працівників по складанню меблів та різноманітних автотранспортних засобів та устаткувань. Індекс реальної заробітної плати становив $109,2 \%$.

Усього за 2018 рік туроператорами та турагентами було обслуговано 21807 тис. осіб у тому числі 448 іноземців, 5963 -внутрішніх туристів та 15396 тис. виїзних туристів.

У 2018 році кількість колективних засобів розміщення становило -72 одиниці, а кількість місць у них становило -3684 одиниць.

Кількість готелів та аналогічних засобів розміщення усього становило - 16 одиниць та інших засобів розміщення налічувалося - 56 одиниць.

У 2017 році у Волинській області було нараховано лише 6 стаціонарних санаторіїв та пансіонатів, які спеціалізувалися на лікуванні туристів та 66 баз відпочинку з 2,5 тис місць у них [1].

Наступна область, яку ми охарактеризуємо по соціально-економічній активності - це Львівська область. Отож за даними Головного управління статистики у Львівській області на 2019 рік кількість населення становила - 2522,0 тис. осіб.

Середньомісячна номінальна заробітна плата на січень-серпень 2019 року становила - 9043,78 тис. грн..

Кількість туристів, які були обслуговані туроператорами та турагентами на 2018 рік становило 182255 тис. осіб, 3 них 7617 тис. осіб було обслуговано в”їзних туристів, 112757 тис. осіб - виїзних туристів та 61881 тис. осіб - внутрішніх туристів.

Кількість колективних засобів розміщення на 2018 рік становила - 129 одиниць, а кількість місць у них становила - 13191 одиниць. Усього готелів та аналогічних засобів розміщення становило -104 одиниці та 25- інших засобів розміщення.

Всього на 2017 рік у Львівській області налічувалося 42 санаторії та пансіонати з лікуванням та 14 баз та інших закладів відпочинку і місцями у них на 1,2 тис. осіб [2].

Наступна область,яка входить до Західного регіонального туристичного ринку -це Рівненська область, яку ми теж охарактеризуємо нижче, використовуючи метод статистики.

За даними Головного управління статистики у Рівненській області на січень-серпень 2019 року кількість населення становила - 1154,9 тис. осіб.

Середня номінальна заробітна плата штатного працівника становила - 9446 тис.грн. Реальна заробітна плата з урахуванням змін споживчих цін у липні 2019 року склала 102,8\%. 
Загальна кількість туристів, обслугованих туроператорами та турагентами становила - 22027 тис. осіб. 3 цісї кількості було обслуговано -20347 тис. - виїзних туристів та 1680 - тис. внутрішніх туристів.

Кількість колективних засобів розміщення на 2018 рік становила - 17 одиниць, а загальна кількість місць у колективних засобах розміщення становила - 1557 одиниць.

Готелів та аналогічних засобів розміщення налічувалося -15 , інших засобів розміщення всього 2 одиниці.

У 2017 році кількість стаціонарних санаторіїв та пансіонатів у Рівненській області налічувалося - 284 одиниці, а баз відпочинку - 1235 одиниць [3].

Наступною областю даного регіону є Тернопільська. Тому простежимо соціально-економічну активність даної області і зробимо певний висновок щодо розвитку туризму на Західному регіональному туристичному ринку.

За даними Головного управління статистики у Тернопільській області кількість населення становило - 1045,9 тис. осіб.

Заробітна плата у Тернопільській області на 2019 рік становила - 8183 тис. грн.

Кількість обслугованих туристів туроператорами та турагентами на 2018 рік становила - 13103 тис. осіб. 3 них 9485 тисяч виїзних туристів та 3618 внутрішніх туристів.

У Тернопільській області всього колективних засобів розміщення становило -14 одиниць, а загальна кількість у них становило - 1267 одиниць.

Діаграма 1

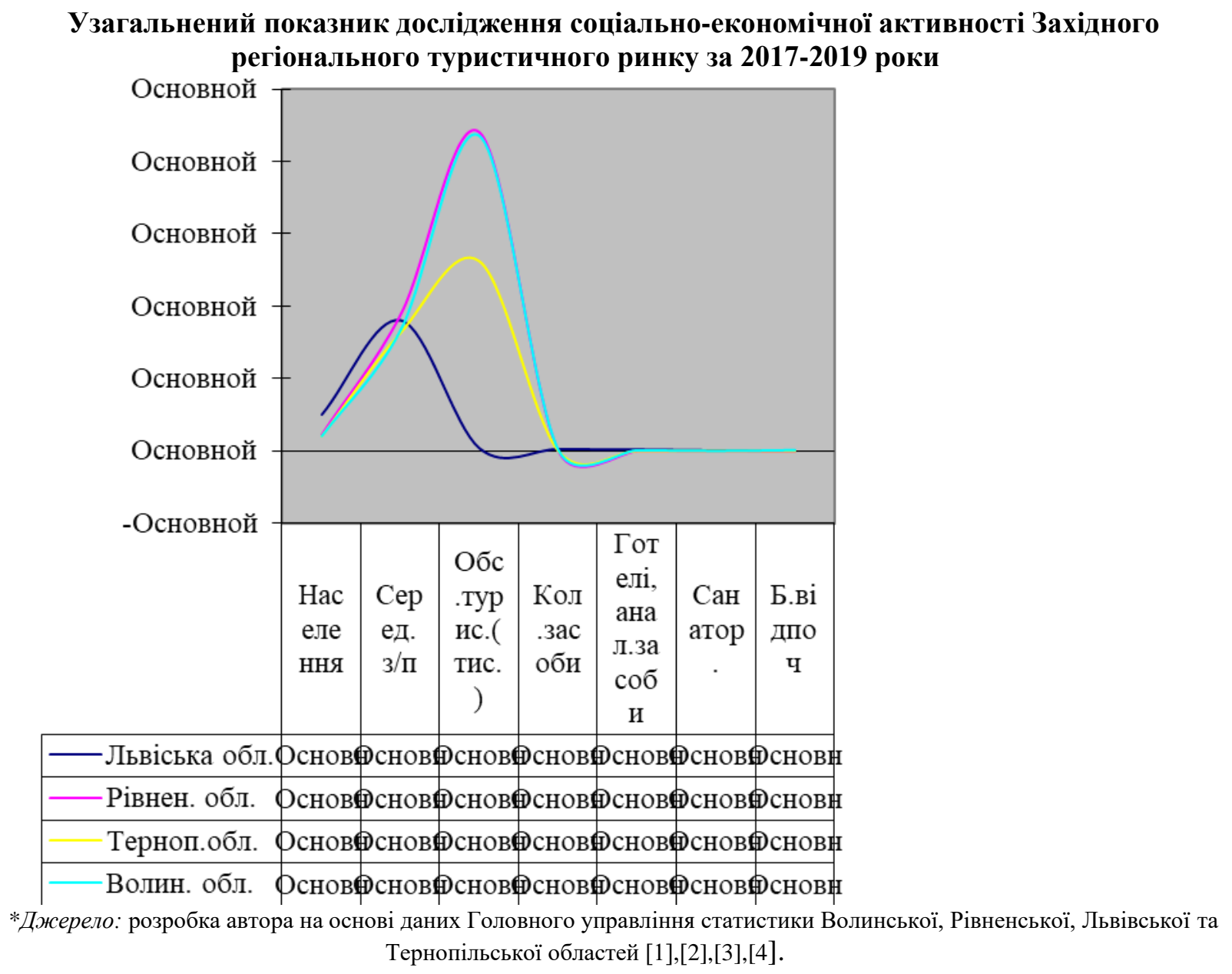

Готелей та аналогічних засобів розміщення -10, інших засобів розміщення налічувалося всього 4. На 2017 рік стаціонарних санаторіїв та пансіонатів налічувалося - 7 одиниць, та 2 бази відпочинку [4]. 
Керуючись результатами аналізу соціально-економічної активності Західного регіонального туристичного ринку включаючи: кількість населення, середню заробітну плату, кількість обслугованих туристів, кількість колективних засобів, кількість готелів та аналогічних засобів та кількість стаціонарних санаторіїв та баз відпочинку, варто простежити рейтинг соціальноекономічної активності Західного регіонального туристичного ринку на діаграмі та виділити найбільш сприятливу область для даного регіону.

3 метою узагальнення результатів дослідження показників соціально-економічної активності Західного регіонального туристичного ринку, в діаграмі виділено рейтингові позиції складових структури регіонального туристичного ринку . Тому можна зробити наступний висновок.

Найбільш рейтинговою областю серед показників соціально-економічної активності є Львівська область, адже кількість туристів на 2018 рік, які були обслугованими турагентствами та туроператорами становить - 182255 тис. осіб. Кількість колективних засобів, готелей та інших засобів розміщення теж $є$ більшою, ніж в дотичних областях Західного регіонального туристичного ринку. Хоча рівень середньої заробітної плати у Рівненській області на 2019 рік був вищим ніж у Львівській, та населення виявилося більше платоспроможними для оформлення путівок за кордон та всередині країни через тур агентів та туроператорів.

Далі для визначення найоптимальнішої області, де найбільше розвивається туристичний ри нок у Західному регіоні застосуємо метод таксономії, тобто присвоїмо певну оцінку області і будемо знати на якій позиції знаходиться кожна область даного регіону.

Тому по методу рейтингування, який ми розглянули вище, Львівська область займає максимальну позицію у Таблиці 1 , тому присвоїмо їй максимальну цифру 4. I тоді по мірі спадання простежимо рейтинг областей у табличному форматі.

Наступну позицію (номер 3) займає Волинська область, адже на меншу кількість населення та нижчу середню заробітну плату - кількість обслугованих туристів становить -21807 тис. осіб та кількість колективних засобів розміщення та готелів теж є більшою, в порівнянні з Рівненською областю. Тому Рівненська область займає позицію під номером 2.

А Тернопільська область 3 не найнижчою кількістю населення, але 3 порівняно низькою кількістю обслугованих туристів та малою кількістю колективних засобів розміщення, готелей та баз відпочинку займає останнє місце серед рейтингу областей Західного регіонального туристичного ринку.

Таблиия 1

Метод рейтингування Західного регіонального туристичного ринку за соціальноекономічними показниками

\begin{tabular}{|l|c|}
\hline Назва області & Метод рейтингування, позиція \\
\hline Західний регіональний туристичний регіон (Волинська обл., Рівненська обл., \\
& Тернопільська обл., Львівська обл.) \\
\hline Львівська область & 4 \\
\hline Волинська область & 3 \\
\hline Рівненська область & 2 \\
\hline Тернопільська область & 1 \\
\hline *Джерело: власна розробка автора
\end{tabular}

У таблиці 1 виділено рейтингові позиції областей ЗРТР по соціально-економічних показниках. Чим світліший колір та менше значення рейтингового числа, тим гіршим є туристичне становище області в порівнянні з іншою. Звідси випливає, що найкраща ситуація та найоптимальніша область для розвитку туризму є Львівська область. Невеликим гірше положення $є$ у Волинській та Рівненській областях. Та не такою успішною у розвитку туристичної діяльності $\epsilon$ Тернопільська область, яка вимагає безліч рекомендацій щодо поліпшення туристичного стану області.

Тому провівши дане дослідження варто сказати, що Львівська область вважається центром розвитку туристичної галузі на Західному регіональному туристичному ринку. Яскравим підтвердженням цього $є$ кількість обслугованих туристів за 2018 рік. Іншим областям, які входять до даного регіону і зайняли нижчі позиції у таблиці 1, варто стимулювати розвиток туристичної галузі, створюючи різноманітні проекти та стратегії розвитку. Також необхідним $є$ корегування державного 
та місцевого регулювання туристичної діяльності, пошук цікавих внутрішніх туристичних маршрутів, реклама та маркетингова діяльність туристичних організацій задля просування туристичної галузі в кожному регіоні.

\section{Висновки та перспективи подальших досліджень}

В даній статті висвітлено рейтинг областей за соціально-економічними показниками. Для повного дослідження ми визначили поняття регіонального туристичного ринку та об'єднали 4 області: Волинську, Рівненську, Львівську та Тернопільську у Західний регіональний туристичний регіон (ЗРТР). Охарактеризували кожну область за такими показниками: кількість населення, середня заробітна плата, кількість обслугованих туристів, кількість колективних засобів, кількість готелів та аналогічних засобів відпочинку, кількість санаторіїв та баз відпочинку. Дослідження проводили за допомогою використання даних Головного управління статистики кожної області. Побудували діаграму та визначали найоптимальнішу область для розвитку туристичного ринку. Далі будували таблицю, де кольорами позначали області по місцю їхньої позиції. Львівська область посіла 4 місце, далі Волинська область- 3, Рівненська область - 2, та Тернопільська - 1. Тобто наймаксимальнішу оцінку отримала Львівська область. Далі ми кольорами зобразили рейтинг областей Західного регіонального туристичного ринку: чим яскравіший колір, тим стан туристичного ринку кращий в порівнянні з іншими областями. Тим областям, які посіли нижчий рівень у рейтингуванні областей варто звернути увагу на місцеве регулювання та поліпшувати свій туристичний потенціал, використовуючи різні стратегії розвитку та проекти модернізації.

Тому в перспективі подальших досліджень варто зосередити увагу на, власне, методи обласних та місцевих органів державного регулювання, а саме на розвиток туристичного ринку в областях. Для модернізації та стимулювання розвитку туристичної галузі в областях, які отримали низькі оцінки в дослідженні рейтингування ЗРТР варто визначити пріоритетні напрями роботи та знайти ті туристичні проекти та стратегії розвитку, які були б найоптимальнішими в тій чи іншій області даного регіону [7].

\section{Джерела та література}

1. Офіційний сайт Головного управління статистики у Волинській області [Електронний ресурс]- Режим доступу: http://www.lutsk.ukrstat.gov.ua/

2 Офіційний сайт Головного управління статистики у Львівській області [Електронний ресурс]- Режим доступу:https://www.lv.ukrstat.gov.ua/

3. Офіційний сайт Головного управління статистики у Рівненській області [Електронний ресурс] :http://www.gusrv.gov.ua

4. Офіційний сайт Головного управління статистики у Тернопільській області [Електронний ресурс]-: http://www.te.ukrstat.gov.ua/statinfoOPSTV.html

5. Зайчук К. А. Врахування досвіду транскордонних країн розвитку туристичного ринку у Волинській області / К. А.Зайчук // Czech Republic, Karlovy Vary - Ukraine, Kyiv, 27 June 2019 [Electronic resource] /Editors prof. L.N. Katjuhin, I.A.Salov, I.S. Danilova, N.S. Burina. - Electron. Txt.d. - Czech Republic, Karlovy Vary: Skleneny Mustek - Ukraine, Kyiv: MCNIP, 2019. - 298-306 c.

6. Зайчук К. А. Регулювання конкурентних відносин між суб'єктами туристичного ринку регіону / К.А. Зайчук, О. М. Стрішенець // Індустрія туризму і сфера гостинності в Україні: сучасний стан, проблеми та перспективи розвитку : матеріали Міжнародної науково-практичної інтернет-конференції з нагоди 10-ої річниці створення кафедри туризму та готельного господарства у Східноєвропейському національному університеті імені Лесі Українки (м. Луцьк, 27 вересня 2018 р.) / відпов. ред. Л. В. Ільїн. - Луцьк : ПП Іванюк В.П., 2018. - С. 10-12.

7. Стрішенець О. М, Зайчук К. А. Пріоритетні напрями функціонування туристичних кластерів у Волинській області / Актуальні проблеми прикладної економіки : [кол.моногр.] / за заг. ред. д-ра екон. наук, проф. О. М. Стрішенець. - Луцьк : Вежа-Друк, 2017.-129-138с

8. Герасимчук 3. В., Черчик Л. М., Регіональна політика розвитку рекреаційного природокористування: механізми формування та реалізації / Луцький держ. Технічний ун-т. - Луцьк: Надстир'я, 2007. - 172 с

9. Павлюк, Т. Д. Управління розвитком регіонального туристичного ринку : автореф. дис. канд. екон. наук : 08.00 .05 / Т. Д. Павлюк ; Прикарпат. нац. ун-т ім. Василя Стефаника. - Івано-Франківськ, 2015. - 20 с.

10. Рогова, О. В. Економічний розвиток регіонів України на засадах реалізації єврорегіонального співробітництва : автореф. дис. канд. екон. наук : 08.00.05 / О. В. Рогова ; Акад. муніципал. упр. - Київ, 2013. $20 \mathrm{c}$. 
11. Туристський словник-довідник: Навч. посіб для студ, аспірантів, викладачів / Київський ін-т туризму економіки і права / В. К. Федорченко, І. М. Мініч. - К. : Дніпро, 2000. - 156с.

\section{References}

1. Ofitsiynyy sayt Holovnoho upravlinnya statystyky u Ternopil's'kiy oblast [Official site of the Main Department of Statistics in Volyn Oblast], from http://www.lutsk.ukrstat.gov.ua/

2. Ofitsiynyy sayt Holovnoho upravlinnya statystyky u L'vivs'kiy oblasti [Official site of the Main Directorate of Statistics in Lviv Oblast], from https://www.lv.ukrstat.gov.ua/

3. Ofitsiynyy sayt Holovnoho upravlinnya statystyky u Rivnens'kiy oblasti [Official site of the Main Department of Statistics in the Rivne region], from http://www.gusrv.gov.ua

4. Ofitsiynyy sayt Holovnoho upravlinnya statystyky u Ternopil's'kiy oblasti [Official site of the Main Department of Statistics in Ternopil region], from http://www.te.ukrstat.gov.ua/statinfoOPSTV.html

5. Zaychuk K. A. (2019). Z urakhuvannyam dosvidu rozvytku transkordonnykh krayin rozvytku turystychnoho rynku Volyni [Taking into account the experience of transboundary countries of tourism market development in Volyn region]. Compiled Mustek Electronic resource, (pp. 298-306) [in Ukrainian].

6.Zaychuk K.A Rehulyuvannya konkurentnykh vidnosyn mizh sub'yektamy turystychnoho rynku rehionu [Regulation of competitive relations between the subjects of the tourist market of the region] / K.A. Zaychuk, O.M Strishenets // Tourism Industry and Hospitality in Ukraine: Current State, Problems and Prospects for Development: Proceedings of the International Scientific and Practical Internet Conference on the Occasion of the 10th Anniversary of the Establishment of the Chair of Tourism and Hotel Management at Lesya Ukrainka Eastern European National University (Lutsk, Ukraine), September 27, 2018) / responded. ed. L.V. Ilyin. - Lutsk: PE Ivanyuk VP, 2018. - P. 1012[in Ukrainian].

7. Strishenets O.M, Zaychuk K.A Priory`tetni napryamy`funkcionuvannya tury`sty`chny`x klasteriv $u$ Voly`ns kij oblasti [Priority directions of tourist clusters functioning in Volyn region] / Current problems of applied economy: [monogr.] / For total. Ed. Dr. Econ. of sciences, prof. OHM. Hornet. - Lutsk: Tower-Printing, 2017.- P.129-138 [in Ukrainian].

8. Gerasymchuk Z.V, Cherchik L.M, Regional`na polity`ka rozvy`tku rekreacijnogo pry`rodokory`stuvannya: mexanizmy formuvannya ta realizaciyi [Regional policy of development of recreational nature management: mechanisms of formation and realization] / Lutsk state. Technical Univ. - Lutsk: Overhang, 2007. - 172 p [in Ukrainian].

9. Pavlyuk, T.D Upravlinnya rozvytkom rehional'noho turystychnoho rynku [Managing the development of the regional tourism market]: abstract. dissertation ... Cand. econom. Sciences: 08.00.05 / TD Pavlyuk; Carpathian. nat. them. Vasily Stefanik. - Ivano-Frankivsk, 2015. - 20 p. [in Ukrainian].

10. Rogova, O.V. Ekonomichnyy rozvytok rehioniv Ukrayiny na zasadakh realizatsiyi yevrorehional'noho spivrobitnytstva [Economic development of the regions of Ukraine on the basis of realization of Euroregional cooperation]: author. dissertation ... Cand. econom. Sciences: 08.00.05 / OV Horny; Acad. the municipality. ref. Kyiv, 2013. - 20 p. [in Ukrainian].

11. Turyst:s'kyy slovnyk-dovidnyk [Travel Dictionary Directory]: Educ. a tool for students, graduate students, teachers / Kiev Institute of Tourism Economics and Law / V.K. Fedorchenko, I.M. Minich. - K .: Dnipro, $2000 .-156$ p. [in Ukrainian]. 